Agata Szuta dyrektor Instyłutu Dialogu Międzykulturowego im. Jana Pawła II Kraków

\title{
Słowo na zakończenie
}

Szanowni Państwo, Czcigodni Księża Profesorowie, zacni Goście,

Instytut Dialogu Międzykulturowego im. Jana Pawła II, który jest współorganizatorem tej konferencji, a któremu mam zaszczyt przewodniczyć, powołany został właśnie po to, aby drogą dialogu podążać za Papieżem, który przez otwarcie na świat i drugiego człowieka budował cywilizację pokoju i miłości. Padło już tutaj tak wiele ważnych słów, że nie sposób wiele więcej dodać. Chciałabym jedynie, podsumowując, bardzo podziękować Państwu za udział w dzisiejszej konferencji oraz jeszcze raz podkreślić, nawiązując tym razem do słów papieża Franciszka, iż dialog dla chrześcijan jest powinnością, jest obowiązkiem. Polega on przede wszystkim na codziennym i konkretnym działaniu oraz budowaniu razem lepszego jutra. Przyszłość ludzkości i budowa cywilizacji zależą od zdolności wzajemnego otwarcia na dialog z drugim. W Kairze papież dobitnie podkreślił, że jedyną alternatywą dla cywilizacji spotkania jest nie cywilizacja starcia, ale dialog, który jest tamą dla przemocy i terroryzmu, a braterstwo pomiędzy wierzącymi jest tlenem, który pozwala oddychać światu. Takiej postawy sobie i nam wszystkim w pełnieniu swoich obowiązków życzę. Dziękuję. 
4. Uniwersytet Papieski

Jes Jana Pawła II

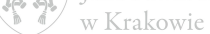

